DOI https://doi.org/10.30525/978-9934-588-79-2-1.31

\title{
ЛАЗЕРНЕ ФОРМОУТВОРЕННЯ СКЛАДНИХ ПРОФІЛІВ З ЛИСТОВИХ МАТЕРІАЛІВ
}

\author{
Кагляк О. Д. \\ кандидат технічних наук, дочент, \\ доиент кафедри лазерної техніки та фізико-технічних технологій \\ Інституту матеріалознавства та зварювання імені $С$. О. Патона \\ Національного технічного університету України \\ «Київький політехнічний інститут імені Ігоря Сікорського» \\ Романов Б. С. \\ аспірант, \\ кафедра лазерної техніки та фізико-технічних технологій \\ Інституту матеріалознавства та зварювання імені $С$. О. Патона \\ Національного технічного університету України \\ «Київський політехнічний інститут імені Ігоря Сікорського» \\ Головко Л. Ф. \\ доктор технічних наук, професор, \\ професор кафедри лазерної техніки та фізико-технічних технологій \\ Інституту матеріалознавства та зварювання імені С. О. Патона \\ Національного технічного університету Украӥни \\ «Київький політехнічний інститут імені Ігоря Сікорського» \\ м. Київ, Украӥна
}

Під час надання листовим матеріалам форм складного профілю за допомогою обробки тиском (зокрема, в універсальних згинальних штампах), виникає ряд обмежень для формування. А саме, розмір мінімальної полички, перекриття доступу інструменту до зони обробки через багаторазове згинання, зворотній пружний ефект, складність формування матеріалів, що мають високу пружність чи крихкість. Використання лазерне формоутворення (ЛФ), дозволяє уникнути цих обмежень. Перевагою ЛФ є гнучкість та швидка переналаштовуваність, відсутність потреби у важкому штамповому обладнанні, можливість формування важкодеформівних матеріалів.

Лазерне формоутворення полягає у формуванні на поверхні матеріалу залишкових термічних напружень, які перевищуючи межу текучості матеріалу, спричиняють залишкові пластичні деформації, надаючи виробу кінцеву форму. Керівними параметрами ЛФ являється 
потужність лазерного променя, розмір зони фокусування, та швидкість переміщення лазерного променя по поверхні зразка [1].

Режим обробки підбирався згідно методики викладеної в [2] при чому він має бути таким, щоб уникати поверхневого оплавлення матеріалу зразка, для недопущення газопоглинання та надлишкового окислення зони обробки.

В якості зразків використовувалися смуги розміром $50 * 200$ мм. товщиною 0.5мм. 3 нержавіючої сталі аустенітного класу 12Х18Н10T. Вибір матеріалу був обумовлений тим, що даній сталі не відбуваються поліморфні перетворення в діапазоні температур, які досягає матеріал під час ЛФ. Таким чином виключався вплив поліморфних перетворень на процес формування. Зразки попередньо відпалювалися, для зняття можливих внутрішніх напружень. Під час опромінення зразок фіксувався за центральну частину, рис 1 .

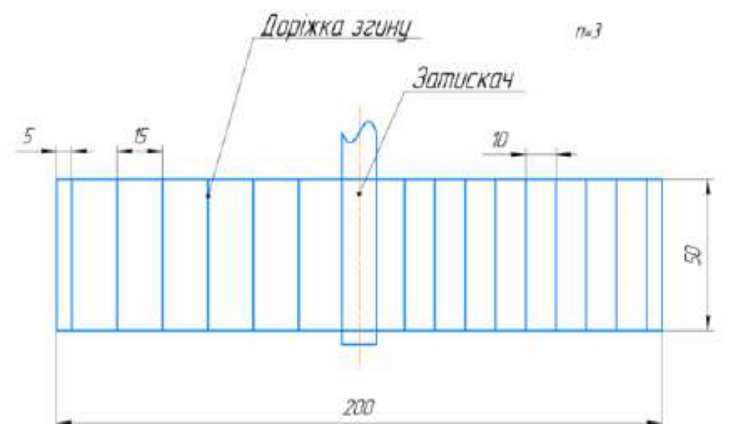

Рис. 1. Схема фіксації зразка під час обробки та один з варіантів розташування траєкторій лазерних проходів.

Обробка зразків проводилася променем твердотільного лазера на ітрій-алюмінієвому гранаті. Базовий режим обробки, що показав достатню ефективність мав потужність променя 350 Вт, швидкість переміщення променя 5 м/хв., діаметр зони фокусування 3 мм. Опромінювання відбувалося за прямолінійними траєкторіями. По кожній траєкторії здійснювалося по три проходи. Варіювався також крок між сусідніми проходами, за двома схемами: фіксований крок на одному зразку, збільшений на наступному; або ж змінний крок.

Бажаний профіль виробу досягається варіюванням режиму одиничного проходу, зміною кількості проходів по одній траєкторії, напрямком сусідніх траєкторій та відстанню між ними. 
В результаті варіювання режимів та умов опромінення вдалося отримати циліндричні, конічні, параболічні поверхні та поверхні 3 варіюванням величини та напрямку кривизни (рис. 2).

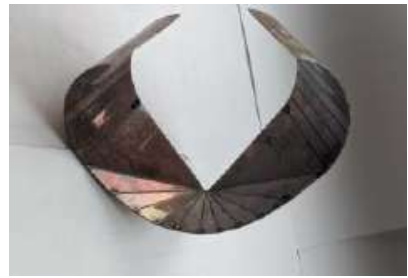

A)

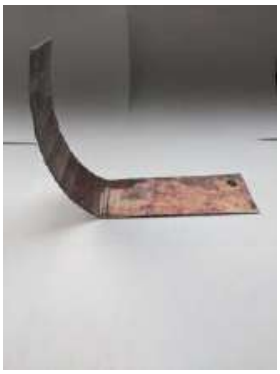

B)

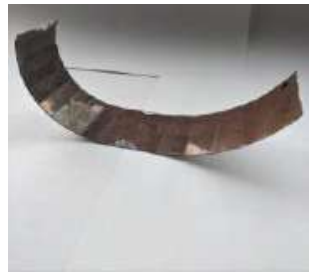

Б)

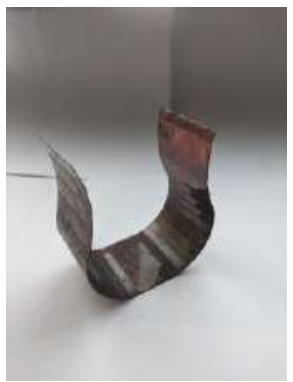

Г)

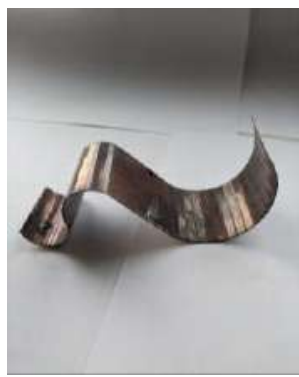

Д)

\section{Рис. 2. Результати обробки}

Зокрема, для отримання конічної поверхні (рис. 2 а, центральна ділянка) проходи необхідно розташовувати віялоподібно, з дотримання сталого значення величини кута між сусідніми зонами опромінення. 
Для отримання циліндричної поверхні (рис. 2 б, г, д) проходи необхідно розташовувати на рівній відстані один від одного. При чому, чим менший радіус циліндричності поверхні потрібно отримати, тим менший крок має бути між сусідніми зонами опромінення. Для отримання параболічної (рис. 2 в), та подібних поверхонь, необхідно застосовувати варіювання кроку між зонами опромінення за певним законом. Зміна напрямку кривизни зразка (рис. 2 г, д) досягалася за рахунок опромінення зразка з протилежних сторін. Оскільки в даному випадку реалізується формувальний механізм градієнту температур, то зразок формувався на зустріч лазерному променю.

Слід зазначити, що додатковим фактором формування може бути застосування криволінійних траєкторій лазерних проходів. Однак, це ускладнить напружено-деформований стан зразка і тому, використання криволінійних траєкторій лазерних проходів, потребує додаткового вивчення.

\title{
Література:
}

1. Кагляк О.Д., Головко Л.Ф., Гончарук О.О. «Лазерне формоутворення просторових металевих конструкцій», Східно-європейський журнал передових технологій. - 2009. - № 6/1(42). Рp. 4-11.

2. Кагляк О. Д. Розроблення програмного модуля вибору режиму обробки для лазерного формування листових матеріалів. Автоматизація та комп'ютерно-інтегровані технології - 2019 VI Міжнародна науковопрактична конференція молодих учених, аспірантів і студентів АКІТ 2019 (Київ, 23-24 квітня 2019 р.) Київ, 2019. С. 124-127.

DOI https://doi.org/10.30525/978-9934-588-79-2-1.32

\section{МОДЕЛІ ФОРМУВАННЯ БУЛЬБАШОК У ГІРНИЧИЙ МАШИНІ ДЛЯ УТИЛІЗАЦІЇ ВТОРИННОЇ ЕНЕРГІЇ}

\author{
Кірсанов М. В. \\ головний конструктор проекту \\ Інституту геотехнічної механіки імені М. С. Полякова \\ Національної академії наук Украӥни \\ м. Дніпро, Україна
}

Сучасні вимоги до ощадливого використання енергоресурсів приводять до необхідності розробки технічних розв'язків, спрямованих на використання вторинних джерел теплової енергії різного походження. 128 